\title{
Effects of Policy Uncertainty on Nominal Rupee-Dollar Exchange Rate in Pakistan
}

\author{
Abdul Waheed
}

\begin{abstract}
This study first attempts to identify the determinants of nominal rupee-dollar exchange rate in Pakistan. Apart from providing theoretical explanation on possible determinants of nominal rupee-dollar exchange rate, the study tests their statistical significance using Cointegration modeling approach. It finds that the relative price, domestic output, current account balance, exports, financial deepening, interest rate differential, and budget deficit turn out to be statistically significant determinants of nominal rupee dollar exchange rate in Pakistan. Furthermore, this paper also analyzes the effects of policy uncertainty on exchange rate behavior using GARCH model. It finds that uncertainty related to output, current account deficit, budget deficit, external debt, and domestic investment contributes to the volatility of nominal rupee-dollar exchange rate in Pakistan.
\end{abstract}

Index Terms-Nominal exchange rate, time series model, policy uncertainty.

\section{INTRODUCTION}

There are two main reasons for the demand for foreign currency. First, foreign currency serves as a medium of exchange as it facilitates trading of goods and services. Second, the foreign currency is hold as an asset in order to benefit from interest rate differential. The depreciation in exchange rate results in high cost of importing capital goods and raw materials, which ultimately increases domestic prices of goods. This may results in decline in domestic production and increase in unemployment in the economy.

Empirical studies have shown that after the Bretton Woods system, nominal exchange rate have been more volatile compare to relative prices at least in short run. It can be argued that fluctuation in real exchange rates originate mainly from fluctuations in nominal exchange rate under floating exchange rate system. Thus, it is necessary to put more attention on nominal exchange rate rather than on real one to formulate an effective exchange rate policy. Given the importance that nominal exchange rate movements have effects on the real economy in small country, identification of its determinants could provide useful information for both policy makers and market participants.

At the time of independence in 1947, Pakistan adopted the Bretton Woods system and fixed the exchange rate against US dollar at rupees 3.32 in 1948. In 1982, the country de-linked the rupee from US dollar and followed floating exchange rate system. Since then the nominal exchange rate with dollar is continuously depreciating and reached to rupees 95.50 per US dollar by October 2012. The contribution of this paper is twofold. First, it will

Manuscript received October 31; revised November 30, 2012.

The author is with the Department of Economics, University of Karachi, Karachi-75270, Pakistan (e-mail:waheedku@yahoo.com). identify the main macroeconomic determinants of nominal bilateral exchange rate of Pakistani rupee vis-à-vis the US dollar. Second, it will use different uncertainty variables related to fiscal, monetary and trade policy to analyze their effects on nominal exchange rate. To the best of our knowledge it is the first empirical analysis on effects of policy uncertainty on nominal exchange rate in the country.

This paper comprises of four sections. Following introduction, Section II discusses the review of theoretical and empirical literature. Section III explains the model, empirical results for order of integration, determinants of nominal exchange rate and the effects of policy uncertainty on nominal exchange rate. Section IV concludes the study and provides the policy implications.

\section{REVIEW OF LITERATURE}

One of the key issues in dominating literature is the identification of the determinants of nominal exchange rate on the basis of which exchange rates could be predicted. Understanding the behavior of exchange rate is important to the policy makers. Despite the importance of the issue, little has been done in the existing literature to understand the behavior of exchange rate and identify those major macroeconomic variables that drive the movement of rupeedollar nominal exchange rate in Pakistan.

Reference [1] investigated the long run determinants of nominal exchange rates in a cross-country analysis. The author identified two kinds of determinants of nominal exchange rate that is long run inflation rate and long run real exchange rate. Among inflation variables, openness and stock of nominal debt were found to affect significantly nominal exchange rate. Central bank independence, country size, political instability and past inflation performance were found weaker determinants. Through long run real exchange rate, output growth was found an important variable in explaining the nominal exchange rate.

Reference [2] identified the factors that lead to the depreciation of the Nigerian exchange rate. The important factors include- low level of output, heavy debt burden, inadequate foreign capital inflow, expansionary monetary and fiscal policies, high demand for foreign exchange, weak balance of payment position, and capital flight.

Reference [3] conducted a study on exchange rate determinants and the dynamics of Euro. The authors estimated a monetary exchange rate model in the form of a Vector Error Correction Model (VECM) and undertook the exchange rate prediction of the euro against the US dollar, the British pound, the Japanses yen, and the Swiss franc. The results confirmed that for the US dollar, the British pound and the Japanese yen the naïve random walk prediction can be outperformed, but not for the Swiss Franc, 
when cointegration analysis was performed.

Reference [4] attempted to determine whether the overshooting is a short run or long run phenomenon. They used money supply, real output, interest rate and inflation rate in the monetary model of nominal exchange rate. They estimated the model employing the Auto Regressive Distributed Lag (ARDL) approach in error correction framework using monthly data over the period 1987-2000. The results showed strong evidence supporting exchange rate overshooting in the short run.

There is also a role of interest rate differential in determining the nominal exchange rate. Higher interest rates may attract foreign capital, which increase the demand for the domestic currency. As a result the domestic currency will appreciate. But there may be a situation where foreigner rather buys shares instead of bonds. If buying of share is the strongest component of currency demand, then an increase in the rate of interest may even lead to the opposite result. This may results outflow of foreign direct investment and nominal exchange rate may depreciate.

An increase in output can affect nominal exchange rate in two ways. First increase output can be used to enhance export and results in inflow of foreign exchange which may appreciate domestic currency. Second, increase income can be used to purchase imported good and may result in high demand for foreign currency, which may cause domestic currency to depreciate. Budget deficit may results depreciation of domestic currency. An increase in budget deficit forces the government to finance it through printing more money (mostly in developing country). This may results excess supply of domestic currency and ultimately depreciation of nominal exchange rate.

\section{Model Estimations AND RESUlts}

\section{A. Model and Data}

Based on the review of theoretical and empirical literature following model is proposed for estimation purpose.

$$
N E R=\beta_{0}+\beta_{i} C V_{i}+\beta_{j} U V_{j}+\mu_{i}
$$

where NER is the nominal exchange rate, that is, Pakistani rupees per US dollar and CV represents a set of macroeconomic variables that affect nominal exchange rate. This study intends to identify such determinants of nominal exchange rate. UV is different policy uncertainty proxies that may affect the nominal exchange rate.

To test the order of integration of variables of the model, the Augmented Dickey Fuller (as in [5]) and Phillip Perron (PP) (as in [6]) tests are employed in this study. The $\mathrm{ADF}$ and PP tests results are shown in Table I. Both tests confirm that all variables, that is, the broad money to gross domestic product ratio (M2GDP); the current account deficit to GDP ratio (CADGDP); the relative price (RP); Export to GDP ratio (EGDP); real GDP (GDPR); London Interbank Offered Rate (LIBOR); Weighted Average Rate of Return on Deposits (WARRD); budget deficit to GDP ratio (BDGDP); are stationary at first difference. Thus, all series are integrated of order one i.e. I(1).

TABLE I: DATA STATIONARITY TEST RESULTS

\begin{tabular}{|c|c|c|c|c|c|c|c|c|}
\hline \multicolumn{5}{|c|}{ Augmented Dickey Fuller test statistics } & \multicolumn{4}{|c|}{ Phillips - Perron test statistics } \\
\hline \multicolumn{3}{|c|}{ Level } & \multicolumn{2}{|c|}{ First difference } & \multicolumn{2}{|c|}{ Level } & \multicolumn{2}{|c|}{ First difference } \\
\hline Variables & $\begin{array}{c}\text { With } \\
\text { constant }\end{array}$ & $\begin{array}{l}\text { With } \\
\text { constant } \\
\text { \& trend }\end{array}$ & $\begin{array}{c}\text { With } \\
\text { constant }\end{array}$ & $\begin{array}{c}\text { With } \\
\text { constant \& } \\
\text { trend }\end{array}$ & $\begin{array}{c}\text { With } \\
\text { constant }\end{array}$ & $\begin{array}{c}\text { With } \\
\text { constant \& } \\
\text { trend }\end{array}$ & $\begin{array}{c}\text { With } \\
\text { constant }\end{array}$ & $\begin{array}{c}\text { With } \\
\text { constant \& } \\
\text { trend }\end{array}$ \\
\hline M2GDP & -2.79 & -3.05 & -4.39 & -4.03 & -2.78 & -2.48 & -4.37 & -4.30 \\
\hline CADGDP & -3.60 & -3.53 & -6.21 & -6.06 & -3.61 & -3.53 & -9.44 & -8.93 \\
\hline $\mathbf{R P}$ & -0.85 & -1.38 & -3.27 & -3.37 & -0.77 & -1.28 & -3.25 & -3.35 \\
\hline EGDP & -2.25 & -1.28 & -4.90 & -5.37 & -2.25 & -0.45 & -4.90 & -5.94 \\
\hline GDPR & 1.45 & -1.11 & -3.64 & -3.90 & -1.89 & -1.02 & -3.49 & -3.74 \\
\hline LIBOR & -1.57 & -4.85 & -6.06 & -6.21 & -2.48 & -3.16 & -4.42 & -4.33 \\
\hline WARRD & 0.04 & -2.06 & -4.45 & -4.53 & -1.38 & -2.20 & -4.82 & -4.73 \\
\hline BDGDP & 0.04 & -3.37 & -5.56 & -5.81 & -0.83 & -3.24 & -8.24 & -10.07 \\
\hline UGDPR & -1.89 & -1.86 & -5.08 & -5.07 & -1.92 & -1.83 & -5.11 & -5.10 \\
\hline UCADGDP & -1.49 & -1.22 & -5.06 & -4.86 & -1.46 & -1.25 & -5.07 & -7.65 \\
\hline UBDGDP & -2.57 & -3.03 & -5.34 & -5.28 & -2.64 & -3.11 & -5.38 & -5.32 \\
\hline UEDEDBT & -1.66 & -2.35 & -5.10 & -4.96 & -1.76 & -2.35 & -5.12 & -4.97 \\
\hline UIGDP & -1.41 & -1.30 & -2.02 & -6.00 & -1.93 & -0.85 & -3.69 & -4.75 \\
\hline
\end{tabular}

\section{B. Determinants of Exchange Rate}

This section explores the desirable economic variables that could be the target of the exchange rate policy. The study uses annual time series data of Pakistan for the floating exchange rate period 1983 to 2010 to identify the determinant of nominal exchange rate.

The estimation results of first part of the model 1 are shown in Table II. which are super consistent. However, the Cointegrating Regression Durbin Watson (CRDW) test is used to check the long run relationship. The CRDW statistics from the above estimation results is 1.79 which is 
higher than the critical value for CRDW test at $1 \%$ level (as in [7]). Thus, the null hypothesis of no cointegration is rejected and the variables in the above model are cointegrated.

TABLE II: LONG RUN DETERMINANTS OF NOMINAL EXCHANGE RATE

\begin{tabular}{|c|c|c|c|c|}
\hline Variable & Coeff. & Std. Er. & t-Stat. & Prob. \\
\hline C & -135.26 & 67.31 & -2.01 & 0.06 \\
\hline CADGDP & -0.77 & 0.23 & -3.31 & 0.00 \\
\hline RP & -19.23 & 3.26 & -5.90 & 0.00 \\
\hline EGDP & -1.88 & 0.55 & -3.45 & 0.00 \\
\hline GDPR & 18.04 & 4.09 & 4.41 & 0.00 \\
\hline INTDIF & -0.81 & 0.30 & -2.73 & 0.01 \\
\hline BDGDP & 0.76 & 0.42 & 1.80 & 0.09 \\
\hline Adj.-R & 0.98 & \multicolumn{2}{|c|}{ F-statistic } & 237.46 \\
\hline $\begin{array}{c}\text { DW } \\
\text { statistics }\end{array}$ & 1.79 & \multicolumn{2}{|c|}{ Probability of (Fstatistic) } & 0.00 \\
\hline
\end{tabular}

The regression results in Table II indicate that the independent variables explain approximately 98 percent variations in the nominal rupee-dollar exchange rate. The Durbin Watson statistic of 1.79 illustrates the absence of autocorrelation. The F-statistic of 237.46 shows the model is overall significant. Thus, our estimated model correctly identifies the main macroeconomic variables that are also pointed out in theoretical literature and previous empirical studies.

The interest differential (INTDIF) variable enters with a negative sign, which indicates that an increase in Pakistani interest rate relative to foreign interest rate leads to an appreciation of Pakistani rupee. The financial deepening (M2GDP) variable has a negative sign, which shows that an increase in financial deepening will result appreciation of Pakistani currency. The current account deficit (CADGDP) and budget deficit (BDGDP) variables are both positive, indicating that an increase in either current account deficit or budget deficit will put pressure on local currency and results in depreciation of Pakistani rupee.

The relative price variable has a negative sign and is statistically significant. The output variable has positive sign, indicating that an increase in domestic income will lead to depreciation of Pakistani rupee. This support the view that an increase in income leads to high demand for imported goods and ultimately demand for dollar, which results in depreciation of rupee. The export to GDP (EGDP) ratio has negative sign, confirming that an increase in export will lead to an appreciation of Pakistani rupee.

Reference [8] showed that if we have small sample then there is a possibility of bias in estimation results. In the Ordinary Least Square (OLS) regression results, $\left(1-\mathrm{R}^{2}\right)$ could be an indicator of the bias and this bias approach to zero as $\mathrm{R}^{2}$ approach to unity. In our case this bias is very small because the value of $\mathrm{R}^{2}$ is 0.98 .

\section{Policy Uncertainty and Exchange Rate}

Exchange rate volatility has real economic cost. During the last century many countries attempted to control fluctuations in nominal exchange rate by imposing regulatory restrictions through monetary measures and by direct intervention in the foreign exchange market. The main goal of this section is to examine how policy uncertainty affect exchange rate. Several macroeconomic variables that are proxy for economic uncertainty are used in this study.

It is assumed that some uncertainty variables have negative impact and some have positive impact on nominal exchange rate. We have used five uncertainty variables in our model, that is, uncertainty related to growth (UGDPR), uncertainty related to current account balance (UCADGDP), uncertainty relate to government budget balance (UBDGDP), uncertainty related to external debt (UEDEBT) and the uncertainty related to domestic investment (UIGDP).

\begin{tabular}{|c|c|c|c|c|c|c|}
\multicolumn{7}{c}{ TABLE III: POLICY UNCERTAINTY AND NOMINAL EXCHANGE RATE } \\
\hline \multirow{2}{*}{ Model 1 } & Model 2 & Model 3 & Model 4 & Model 5 & Model 6 \\
\hline \multirow{2}{*}{ C } & -135.26 & -97.62 & -34.72 & -135.29 & -66.32 & 26.86 \\
& $(0.06)$ & $(0.16)$ & $(0.65)$ & $(0.06)$ & $(0.29)$ & $(0.76)$ \\
\hline \multirow{2}{*}{ M2GDP } & -0.77 & -0.90 & -0.92 & -0.52 & -0.40 & -1.01 \\
& $(0.00)$ & $(0.00)$ & $(0.00)$ & $(0.07)$ & $(0.09)$ & $(0.00)$ \\
\hline \multirow{2}{*}{ CADGDP } & 0.070 & 0.05 & 0.10 & 0.07 & 0.06 & 0.09 \\
& $(0.03)$ & $(0.01)$ & $(0.00)$ & $(0.04)$ & $(0.04)$ & $(0.00)$ \\
\hline \multirow{2}{*}{ RP } & -19.23 & -23.20 & -25.94 & -19.94 & -24.10 & -16.67 \\
& $(0.00)$ & $(0.00)$ & $(0.00)$ & $(0.00)$ & $(0.00)$ & $(0.00)$ \\
\hline \multirow{2}{*}{ EGDP } & -1.88 & -1.45 & -1.31 & -2.03 & -2.04 & -1.82 \\
& $(0.00)$ & $(0.00)$ & $(0.02)$ & $(0.00)$ & $(0.00)$ & $(0.00)$ \\
\hline \multirow{2}{*}{ GDPR } & 18.03 & 13.98 & 11.09 & 17.90 & 10.77 & 10.16 \\
& $(0.00)$ & $(0.00)$ & $(0.03)$ & $(0.00)$ & $(0.04)$ & $(0.05)$ \\
\hline \multirow{2}{*}{ INTD } & -0.81 & -0.99 & -0.76 & -0.44 & -0.09 & -0.73 \\
& $(0.01)$ & $(0.00)$ & $(0.02)$ & $(0.23)$ & $(0.79)$ & $(0.02)$ \\
\hline \multirow{2}{*}{ BDGDP } & 0.75 & 0.38 & 0.59 & 0.38 & 0.10 & 0.83 \\
& $(0.09)$ & $(0.36)$ & $(0.14)$ & $(0.39)$ & $(0.80)$ & $(0.04)$ \\
\hline Uncertainty & & UGDPR & UCADGDP & UBDGDP & UEDEBT & UIGDP \\
\hline Variables & & -3.5 & -9.54 & 2.79 & -3.51 & 6.52 \\
& & $(0.02)$ & $(0.01)$ & $(0.05)$ & $(0.00)$ & $(0.01)$ \\
\hline \multirow{2}{*}{ Adj.-R ${ }^{2}$} & 0.98 & 0.99 & 0.99 & 0.99 & 0.99 & 0.99 \\
\hline F stat. & 237.46 & 237.29 & 242.54 & 216.33 & 308.60 & 243.01 \\
\hline DW stat. & 1.79 & 1.59 & 2.08 & 1.89 & 1.86 & 2.04 \\
\hline
\end{tabular}


The literature uses several methods to proxy uncertainty variable such as standard deviation of the variable, five year moving average or five years moving standard deviation, the conditional variance estimated from Generalized Autoregressive Conditional Hetroscedasticity (GARCH) (as in [9]).

The conditional variances of economic growth, current account balance, budget balance, external debt, and domestic investment variables were estimated from GARCH model to generate relevant uncertainty variable. The effect of all five uncertainty variables were observed in separate regression model and the results are reported in Table III.

The effects of policy uncertainty variables are shown from Model-2 to Model-6 in Table III. The uncertainty related to output, current account, and external debt has significant negative effect on nominal exchange rate, while uncertainty related to budget deficit and investment has significant positive effect on nominal exchange rate. A large coefficient of these uncertainty variables show that such uncertainties contribute mainly to the high volatility of nominal exchange rate in Pakistan. The higher budget deficit uncertainty leads to the depreciation of Pak rupee against US dollar. The increase in domestic investment uncertainty also leads to depreciation of Pak rupee against US dollar.

\section{CONCLUSION AND IMPLICATIONS}

Since the collapse of the Bretton-Woods system of fixed exchange rates, the nominal exchange rate fluctuates widely within the countries. It is believed that exchange rate volatility has negative effects on international trade. This study tried to determine the key macroeconomic variables that affects nominal exchange rate in the first instance. Then, the constructed model was used to find the effects of different macroeconomic uncertainty variables on nominal exchange rate.

The results of the models indicate that a current account and budget deficit result in the depreciation of Pak-rupees against US dollar. This is in accordance with the theoretical underpinnings and empirical evidence. On the other hand increase in domestic interest rate, relative price, exports and financial deepening appreciates domestic currency

Measure aims at improving the current account and budgetary position are instrumental in stabilizing the exchange rate. The increase export earnings also has positive role in stabilizing nominal exchange rate. Thus, it is imperative that Pakistan should diversify into other foreign exchange earnings sources. This will ensure exchange rate stability, which is a prerequisite for economic growth.

\section{REFERENCES}

[1] P. R. Lane, "What determines the nominal exchange rate? Some cross-sectional evidence," The Canadian Journal of Economics, vol. 32, no. 1, pp. 118-38, 1999.

[2] M. I. Obadan, "Overview of exchange rate management in Nigeria from 1986 to date," in The Dynamics of Exchange Rate in Nigeria, Central Bank of Nigeria Bulliton, vol. 30, no. 3, 2006, pp. 1-9, 2006.

[3] B. Aarle, M. Boss, and J. Hlouskova, "Forecasting the Euro excghange rate using vector error correction models," Weltwirtschaftliches Archier, Bd. 136, H. 2, pp. 232-258, 2000.

[4] B. M. Oskee and N. Panthamit, "Exchange rate overshooting in EastAsian countries," Emerging Markets Finance \& Trade, vol. 42, no. 4, pp. 5- 18, 2006.

[5] D. A. Dickey and W. A. Fuller, "Distribution of the estimation for autoregressive time series with a unit root," Journal of American Statistical Association, vol. 79, pp. 355-367, 1979

[6] P. C. B. Phillips and P. Perron, "Testing for a unit root in time series regressions," Biometrika, vol. 75, pp. 335-346, 1988.

[7] D. N. Gujarati, Basic Econometric, McGraw-Hill, pp. 824, 2004.

[8] A. Banerjee, J. Dolado, J. W. Galbraithy, and D. Hendry, Cointegration, error correction and the Econometric analysis of nonstationary data, Oxford: Oxford University Press, pp. 274-75, 1993.

[9] R. K. Goel and R. Ram, "Irreversibility of R\&D investment and the adverse effect of uncertainty: evidence from the OECD countries," Economics Letters, vol. 71, pp. 287-291, 2001.

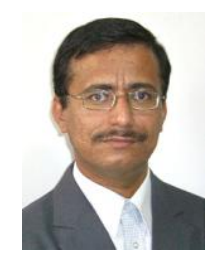

Abdul Waheed was born in Gambat, Pakistan on 21st November 1968. He received his Ph.D. degree from Nagoya University Japan in 2005. Besides that he also conducted post doctoral research in the same university under JSPS fellowship and at IDE Tokyo. He has published several research papers in international journals and completed research projects of different organizations. Currently he is Associate Professor and Chairman at the Department of Economics, University of Karachi, Karachi, Pakistan. His areas of interest are policy reforms in developing countries and financial macroeconomic modeling analysis. 